\title{
Spasmolytic Action of the Methanol Extract and Isojuripidine from Solanum asterophorum Mart. (Solanaceae) Leaves in Guinea-Pig Ileum
}

\author{
Rita de Cassia Meneses Oliveira ${ }^{\text {a,b,c }}$, Julianeli T. Lima ${ }^{a}$, Luciano A. A. Ribeiro ${ }^{a}$, \\ Joelmir L. V. Silva ${ }^{a}$, Fabio S. Monteiro ${ }^{a}$, Temilce S. Assis ${ }^{\mathrm{a}, \mathrm{d}}$, Maria de F. Agra ${ }^{\mathrm{a}, \mathrm{e}}$, \\ Tania M. S. Silva ${ }^{a}$, Fernanda R. C. Almeidac ${ }^{\mathrm{c}}$, and Bagnólia A. Silva ${ }^{\mathrm{a}, \mathrm{e}, *}$ \\ a Laboratório de Tecnologia Farmacêutica, Universidade Federal da Paraíba, P.O. Box 5009, \\ 58051-970, João Pessoa, Paraíba, Brazil. Fax: +55-83-3216-7502. \\ E-mail: bagnolia@ltf.ufpb.br. \\ b Departamento de Biofísica e Fisiologia, Universidade Federal do Piauí, 64049-550, \\ Teresina, Piauí, Brazil \\ c Núcleo de Pesquisas em Plantas Medicinais, Universidade Federal do Piauí, 64049-550, \\ Teresina, Piauí, Brazil \\ d Departamento de Fisiologia e Patologia, Universidade Federal da Paraíba, 58051-970, \\ João Pessoa, Paraíba, Brazil \\ e Departamento de Ciências Farmacêuticas, Universidade Federal da Paraíba, 58051-970, \\ João Pessoa, Paraíba, Brazil \\ * Author for correspondence and reprint requests \\ Z. Naturforsch. 61c, 799-805 (2006); received March 20/May 16, 2006
}

Solanum asterophorum Mart. (Solanaceae) is a shrub popularly known as "jurubeba-defogo" in the northeast of Brazil. In the present work, the methanol extract (SA-MeOH, $3-$ $750 \mu \mathrm{g} / \mathrm{mL})$ and isojuripidine $\left(10^{-7}-3 \times 10^{-4} \mathrm{M}\right)$, a steroidal alkaloid obtained from S. asterophorum Mart. leaves, inhibited phasic contractions induced by both $1 \mu \mathrm{M}$ histamine $\left[\mathrm{IC}_{50}=\right.$ $(225.8 \pm 47.4) \mu \mathrm{g} / \mathrm{mL}$ and $\left.(3.5 \pm 0.8) \times 10^{-5} \mathrm{M}\right]$ or $1 \mu \mathrm{M}$ acetylcholine $\left[\mathrm{IC}_{50}=(112.5 \pm\right.$ $20.6) \mu \mathrm{g} / \mathrm{mL}$ and $\left.(2.3 \pm 0.4) \times 10^{-5} \mathrm{M}\right]$ in guinea-pig ileum, respectively. The extract and isojuripidine also relaxed the ileum (SA-MeOH, $1-750 \mu \mathrm{g} / \mathrm{mL}$, and isojuripidine, $10^{-9}-3 \times$ $\left.10^{-4} \mathrm{M}\right)$ pre-contracted with $1 \mu \mathrm{M}$ histamine $\left[\mathrm{EC}_{50}=(101.1 \pm 17.4) \mu \mathrm{g} / \mathrm{mL}\right.$ and $(1.2 \pm$ $0.3) \times 10^{-6} \mathrm{M}$ ] or $1 \mu \mathrm{M}$ acetylcholine $\left[\mathrm{EC}_{50}=(136.8 \pm 21.1) \mu \mathrm{g} / \mathrm{mL}\right.$ and $(1.9 \pm 0.4) \times 10^{-6} \mathrm{M}$ ] or $40 \mathrm{mM} \mathrm{KCl}\left[\mathrm{EC}_{50}=(149.4 \pm 19.5) \mu \mathrm{g} / \mathrm{mL}\right.$ and $\left.(1.8 \pm 0.7) \times 10^{-6} \mathrm{M}\right]$, respectively, in an equipotent and concentration-dependent manner. This effect is probably due to inhibition of calcium influx through voltage-operated calcium $\left(\mathrm{Ca}_{\mathrm{v}}\right)$ channels. To confirm this hypothesis, we evaluated their effect on cumulative $\mathrm{CaCl}_{2}$ curves in depolarizing medium nominally without $\mathrm{Ca}^{2+}$. SA-MeOH $(27,243,500$, and $750 \mu \mathrm{g} / \mathrm{mL})$ and isojuripidine $\left(3 \times 10^{-8}, 10^{-6}\right.$, $3 \times 10^{-5}$, and $3 \times 10^{-4} \mathrm{M}$ ) inhibited the contractions induced by $\mathrm{CaCl}_{2}$, in a concentrationdependent manner. The concentration-response curves to $\mathrm{CaCl}_{2}$, in the presence of SA$\mathrm{MeOH}$ and isojuripidine, were shifted downward in relation to a control curve in a nonparallel manner resulting in reduction of the maximum effect $\left[\mathrm{E}_{\max }=(71.2 \pm 9.2) ;(57.4 \pm\right.$ 9.2); (43.8 \pm 3.4$)$; (41.5 \pm 2.4$)$ and $(90.6 \pm 4.8)$; $(74.7 \pm 8.7)$; $(66.4 \pm 3.9)$; $(31.3 \pm 4.1) \%$, respectively]. SA-MeOH and isojuripidine present spasmolytic action in guinea-pig ileum due to a partially blockade of calcium influx through $\mathrm{Ca}_{\mathrm{v}}$ channels.

Key words: Solanum asterophorum, Spasmolytic Action, Guinea-Pig Ileum

\section{Introduction}

The Solanaceae family, one of the biggest families distributed worldwide, comprises approx. 92 genera and 2300 species (Hunziker, 2001). The Solanum genus is considered as one of the largest among the angiosperms with approx. 1250 species (Nee, 2001). It is a rich source of active secondary metabolites. Many species of Solanum are popularly known as "jurubeba". Plants of this genus are known to produce a great variety of steroidal saponins and glycoalkaloids that are important in the plants natural resistance against several pests (Friedman et al., 1991).

In Brazil, several species of Solanum (S. paniculatum L., S. melongena L. and S. stipulaceum Roem \& Schult.) were reported to induce hypotension in rats (Ribeiro et al., 1986; Almeida et al., 1984; Shum and Chiu, 1991; Ribeiro, 2001). Moreover other species also presented significant spasmolytic effects, for example, S. indicum L., S. paludosum Moric., S. torvum Sw., S. melongena L. and S. dulcamara L. (Shum and Chiu, 1991; Bha- 
kuni et al., 1969; Silva et al., 2002; Ataíde, 1982; Abraham et al., 1986; Boyd, 1928).

Solanum asterophorum Mart. is a shrub popularly known in the northeast of Brazil as "jurubeba-de-fogo". This rare species, included in the Leptostemonum subgenus, presents a restricted distribution in the states of Bahia and Paraíba and it is used in folk medicine to treat hepatic symptoms (Agra and Bhattacharyya, 1999). This plant was chosen based on chemotaxonomic criteria since the Solanum genus is rich in secondary metabolites with pharmacological activity (Silva et al., 2005a, b).

A search in the NAPRALERT database (Natural Products ALERT) and Web of Science did not show any biological data published.

As part of our chemical and pharmacological studies on Brazilian Solanum (Silva et al., 2005a, b) we report the spasmolytic effect of isojuripidine and the S. asterophorum leaves methanol extract (SA-MeOH) in isolated guinea-pig ileum for the first time.

\section{Material and Methods}

\section{Plant material}

Leaves of S. asterophorum Mart. were collected in June 2003 near the city of Areia, state of Paraíba, Brazil. The plant was collected and determined by Dr. Maria de Fátima Agra. A voucher specimen (Agra 6002) has been deposited in the Herbarium Lauro Pires Xavier (JPB) and the reference collection from Laboratório de Tecnologia Farmacêutica (LTF) both from the Universidade Federal da Paraíba (UFPB), João Pessoa, Brazil.

\section{Extraction and isolation}

The powdered leaves of S. asterophorum $(396.0 \mathrm{~g})$ were extracted with $\mathrm{MeOH}$ in a Soxhlet apparatus. The extract was concentrated under vacuum in a rotaevaporator. The crude residue $(37.5 \mathrm{~g})$, after standing in the refrigerator, furnished a white precipitate that was separated from the extract and recrystallized from methanol to yield $205.0 \mathrm{mg}$ of isojuripidine (25R-3 $\beta$-amino-5$22 \alpha$-O-spirostan-6 $\alpha$-ol, Fig. 1) (Silva et al., 2005b). Both the dry SA-MeOH extract and the isojuripidine crystals were solubilized in cremophor, and then diluted in distilled water in a concentration of $10 \mathrm{mg} / \mathrm{mL}$ and $10^{-2} \mathrm{M}$, respectively. These solutions were maintained at $0{ }^{\circ} \mathrm{C}$, and diluted to their

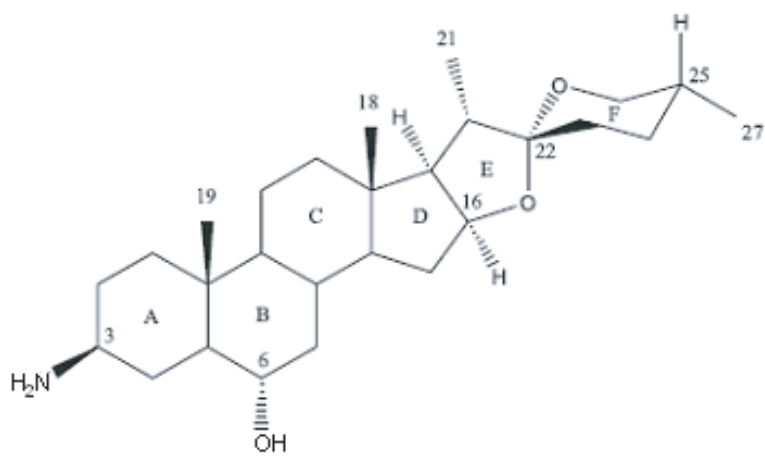

Fig. 1. Chemical structure of isojuripidine.

final concentrations in cubes during the experimental procedure.

\section{Animals}

Adult guinea-pigs of both sexes (Cavia porcellus, 350-500 g) were obtained from the Thomas George Biotery, LTF/UFPB. The animals had free access to food and water and were kept in rooms maintained at $(22 \pm 1){ }^{\circ} \mathrm{C}$ with a 12 -h light-dark cycle and fasting of $18 \mathrm{~h}$ before experiments. The experimental procedure was approved by the Animal Experimentation Committee of the Universidade Federal da Paraíba (Protocol 0512/2005).

\section{Study of spasmolytic activity of SA-MeOH and isojuripidine}

Tissue preparation

To perform in vitro studies, the guinea-pig ileum was prepared according to Daniel et al. (2001). Guinea-pigs were killed by cervical dislocation, exsanguinated and the ileum was immediately removed. The terminal portions, $3 \mathrm{~cm}$ in length, were used after discarding the $10 \mathrm{~cm}$ portion close to the ileocaecal junction. The tissues were placed vertically in $6 \mathrm{~mL}$ isolated organ baths containing modified Krebs solution with the following composition (mM): $\mathrm{NaCl}$ (117), $\mathrm{KCl}$ (4.7), $\mathrm{CaCl}_{2}$ (2.5), $\mathrm{MgSO}_{4}$ (1.3), $\mathrm{NaH}_{2} \mathrm{PO}_{4}$ (1.2), $\mathrm{NaHCO}_{3}$ (25), glucose (11), bubbled with a mixture of $95 \% \mathrm{O}_{2}$ and $5 \% \mathrm{CO}_{2}$ and maintained at $37^{\circ} \mathrm{C}, \mathrm{pH}$ 7.4. Tension changes were recorded through an isometric force transducer (7003) counterbalanced by $1 \mathrm{~g}$ loading, connected to a polygraph (Gemini 7070), both from Ugo Basile (Italy). Phasic contractions were recorded using isotonic levers coupled to kymographs and smoked drums (DTF, Brazil). The tissues were allowed to stabilize for $30 \mathrm{~min}$ at a rest- 
ing tension of $1 \mathrm{~g}$. During the stabilization period the modified Krebs solution was changed every $10 \mathrm{~min}$ to avoid accumulation of metabolites (Altura and Altura, 1970).

Effect of SA-MeOH or isojuripidine on histamine- or acetylcholine-induced contractions in guinea-pig ileum

At the beginning of each experiment, the reactivity of tissue preparations was tested with $40 \mathrm{~mm}$ $\mathrm{KCl}$. After washout and $15 \mathrm{~min}$ recovery in modified Krebs solution, two simple concentration-response curves were obtained for either histamine or acetylcholine $(1 \mu \mathrm{M})$. Various concentrations of the methanol extract (SA-MeOH) or isojuripidine were added and, after an incubation period of $15 \mathrm{~min}$, a third concentration-response curve was constructed in the presence of SA-MeOH or isojuripidine. The tissue was washed when the agonist responses returned to the resting level. Inhibition was measured by comparing the response before $(100 \%)$ and after addition of SA-MeOH or isojuripidine in the organ bath. $\mathrm{IC}_{50}$ values were obtained graphically from simple concentration-response curves.

\section{Mechanism of action of SA-MeOH and isojuripi- dine on guinea-pig ileum}

Effect of SA-MeOH or isojuripidine on tonic contractions induced by histamine, acetylcholine or $\mathrm{KCl}$

After stabilization of the preparations, an isometric contraction was elicited with $1 \mu \mathrm{m}$ histamine, $1 \mu \mathrm{M}$ acetylcholine or $40 \mathrm{~mm} \mathrm{KCl}$. Histamine, acetylcholine or $\mathrm{KCl}$ remained in contact with the preparation until a plateau of contraction was reached (approx. $8 \mathrm{~min}$ ). Thereafter the tissue was washed. After further $30 \mathrm{~min}$, the process was repeated and SA-MeOH or isojuripidine was added cumulatively at the plateau phase. Relaxation was expressed as the reverse of initial contraction elicited by histamine, acetylcholine or $\mathrm{KCl}$.

Effect of SA-MeOH or isojuripidine on $\mathrm{Ca}^{2+}{ }_{-}$ induced contractions in depolarizing medium nominally without $\mathrm{Ca}^{2+}$

After a $30 \mathrm{~min}$ stabilization period, modified Krebs solution was changed by a depolarized solution nominally without $\mathrm{Ca}^{2+}$ during further $45 \mathrm{~min}$. Two similar $\mathrm{CaCl}_{2}$ cumulative response-concentration curves were then induced at $60 \mathrm{~min}$ intervals and recorded through isometric transducers cou- pled to a polygraph. After this procedure the organ baths were washed, and several concentrations of SA-MeOH or isojuripidine were incubated for $15 \mathrm{~min}$ in different preparations and then a third $\mathrm{CaCl}_{2}$ cumulative curve was obtained. The maximal contraction obtained with the first concentration-response curve to $\mathrm{CaCl}_{2}$ was considered as $100 \%$, and all contractions were calculated proportionally to this value.

\section{Statistical analysis}

Values were expressed as means \pm S.E.M. Statistical analysis was performed using the GraphPad Prism ${ }^{\circledR} 3.03$ software (GraphPad Software Inc., San Diego, CA). The $\mathrm{EC}_{50}$ and $\mathrm{IC}_{50}$ values were determined by non-linear regression (Jenkinson et al., 1995). Differences between means were statistically compared using Student's $t$-test and/or one-way ANOVA followed by Bonferroni's test, as appropriate, and were considered to differ significantly when $p<0.05$. Schild plots were also analyzed by a linear regression. Antagonism was judged to be non-competitive when the slope of the Schild's plot was significantly different from unity (Arunlakshana and Schild, 1959) and depression of the maximum response was observed (Van Rossum, 1963).

\section{Results}

Effect of SA-MeOH and isojuripidine on histamine- or acetylcholine-induced contractions in guinea-pig ileum

SA-MeOH $(3-750 \mu \mathrm{g} / \mathrm{mL})$ and isojuripidine $\left(10^{-7}-3 \times 10^{-4} \mathrm{M}\right)$ inhibited phasic contractions induced by either histamine (Fig. 2) or acetylcholine (Fig. 3). The corresponding $\mathrm{IC}_{50}$ values obtained for histamine and acetylcholine, respectively, were $(225.8 \pm 47.4)$ and $(112.5 \pm 20.6) \mu \mathrm{g} /$ $\mathrm{mL}$ for $\mathrm{SA}-\mathrm{MeOH}$, and $(3.5 \pm 0.8)$ and $(2.3 \pm$ $0.4) \times 10^{-5} \mathrm{M}$ for isojuripidine.

\section{Effect of SA-MeOH and isojuripidine on tonic contractions induced by histamine, acetylcholine or $\mathrm{KCl}$}

SA-MeOH $(1-750 \mu \mathrm{g} / \mathrm{mL})$ or isojuripidine $\left(10^{-9}-3 \times 10^{-4} \mathrm{M}\right)$ relaxed histamine- $\left[\mathrm{EC}_{50}=\right.$ $(101.1 \pm 17.4) \mu \mathrm{g} / \mathrm{mL}$ and $\left.(1.2 \pm 0.3) \times 10^{-6} \mathrm{M}\right]$, acetylcholine- $\left[\mathrm{EC}_{50}=(136.8 \pm 21.1) \mu \mathrm{g} / \mathrm{mL}\right.$ and $\left.(1.9 \pm 0.4) \times 10^{-6} \mathrm{M}\right]$ or $\mathrm{KCl}-\left[\mathrm{EC}_{50}=(149.4 \pm\right.$ $19.5) \mu \mathrm{g} / \mathrm{mL}$ and $\left.(1.8 \pm 0.7) \times 10^{-6} \mathrm{M}\right]$ pre-con- 
A

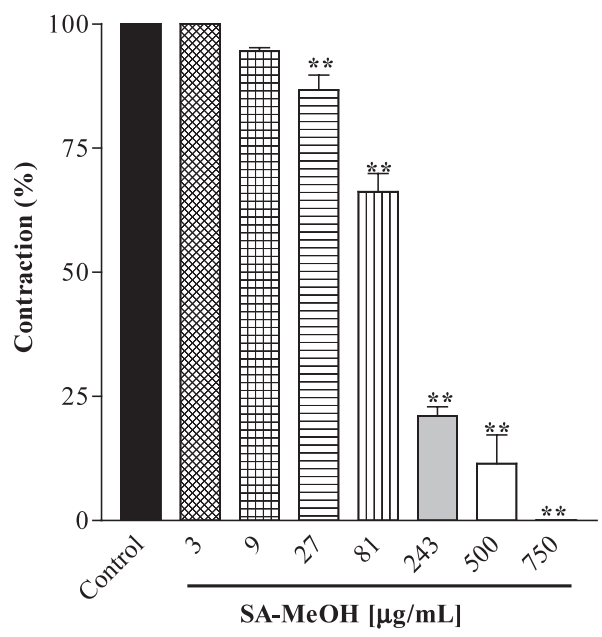

B

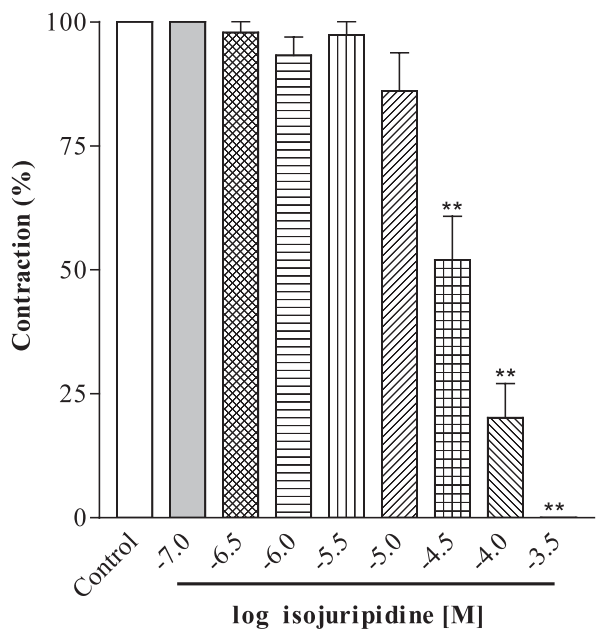

Fig. 2. Effect of SA-MeOH (A, $n=5)$ and isojuripidine $(\mathrm{B}, n=3)$ on phasic contractions induced by $1 \mu \mathrm{M}$ histamine in guinea-pig ileum. The columns and bars represent means \pm S.E.M., respectively. Significant differences are indicated by $* * p<0.001$ (control $\times \mathrm{SA}-\mathrm{MeOH}$ or isojuripidine; one-way ANOVA followed by Bonferroni's test).

tracted guinea-pig ileum in an equipotent and concentration-dependent manner (Fig. 4).

Effect of SA-MeOH and isojuripidine on $\mathrm{Ca}^{2+}$ induced contractions in depolarizing medium nominally without $\mathrm{Ca}^{2+}$

SA-MeOH $(27,243,500$, and $750 \mu \mathrm{g} / \mathrm{mL})$ or isojuripidine $\left(3 \times 10^{-8}, 10^{-6}, 3 \times 10^{-5}\right.$, and $3 \times$
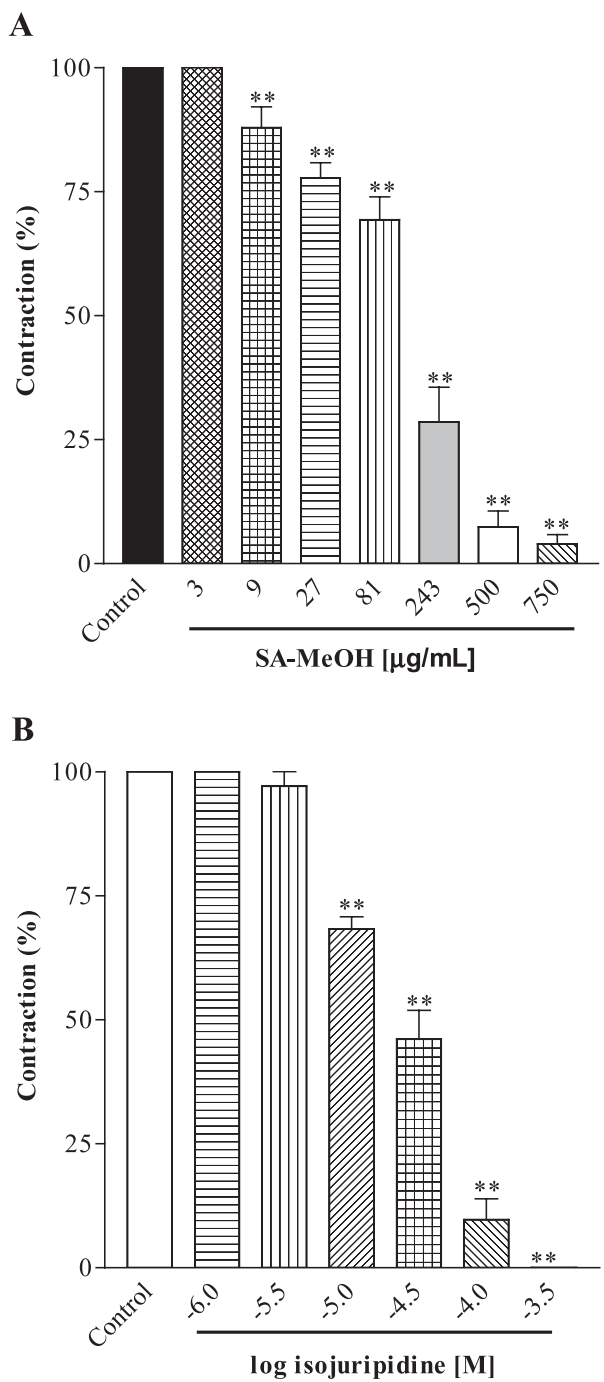

Fig. 3. Effect of SA-MeOH (A, $n=5)$ and isojuripidine $(\mathrm{B}, n=3)$ on phasic contractions induced by $1 \mu \mathrm{M}$ acetylcholine in guinea-pig ileum. The columns and bars represent means \pm S.E.M., respectively. Significant differences are indicated by $* * p<0.001$ (control $\times \mathrm{SA}-\mathrm{MeOH}$ or isojuripidine; one-way ANOVA followed by Bonferroni's test).

$10^{-4} \mathrm{M}$ ) inhibited the contractions induced by $\mathrm{CaCl}_{2}$ in a concentration-dependent manner. The cumulative concentration-response curves to $\mathrm{CaCl}_{2}$, in the presence of $\mathrm{SA}-\mathrm{MeOH}$ and isojuripidine, were shifted downward in relation to a control curve in a non-parallel manner resulting in reduction of the maximum effect $\left[\mathrm{E}_{\max }=(71.2 \pm 9.2)\right.$; $(57.4 \pm 9.2) ;(43.8 \pm 3.4) ;(41.5 \pm 2.4)$ and $(90.6 \pm$ 
A

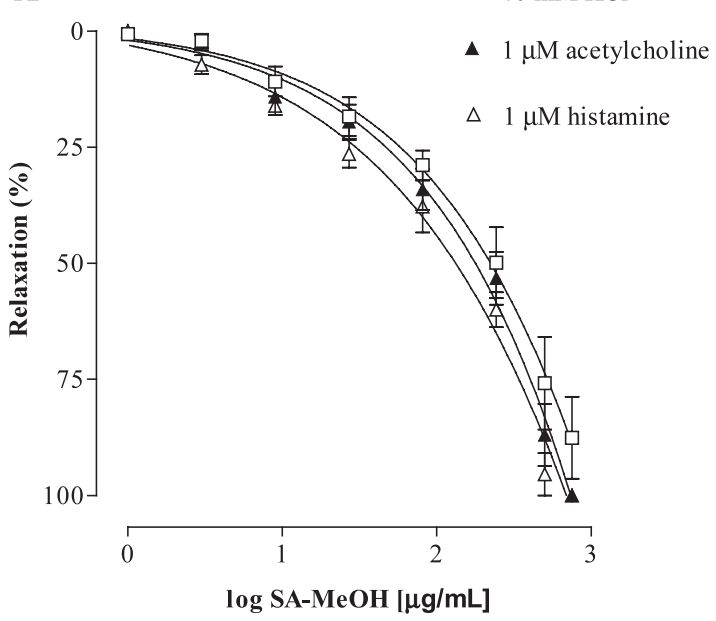

B

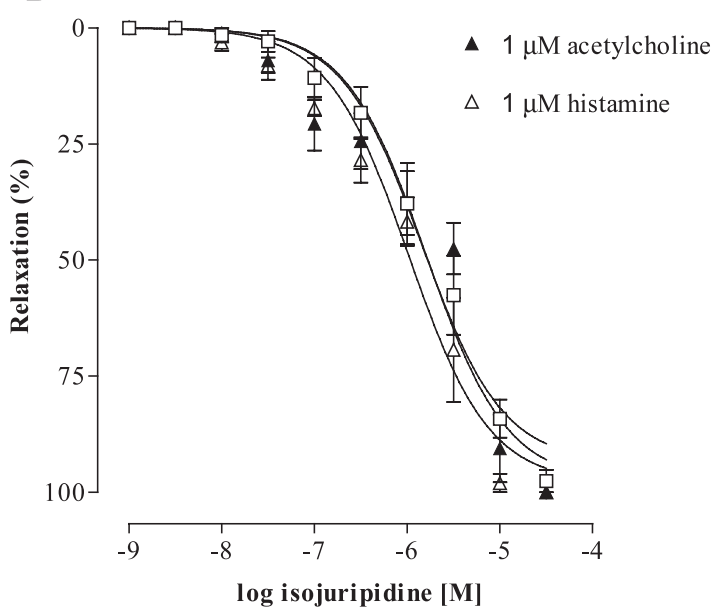

Fig. 4. Effect of several concentrations of SA-MeOH (A, $n=5)$ and isojuripidine $(\mathrm{B}, n=4)$ on the $1 \mu \mathrm{M}$ histamine-, $1 \mu \mathrm{M}$ acetylcholine- or $40 \mathrm{~mm} \mathrm{KCl-induced} \mathrm{tonic} \mathrm{contrac-}$ tions in guinea-pig ileum. The symbols and vertical bars represent means \pm S.E.M.

4.8); (74.7 \pm 8.7$) ;(66.4 \pm 3.9) ;(31.3 \pm 4.1) \%]$ for isojuripidine. This data suggests a non-competitive antagonism (Fig. 5), that was corroborated by Schild's slope value $(0.2537 \pm 0.1073)$, which was statistically different from 1 . Linear regression analysis of the data showed a low correlation coefficient value $\left(r^{2}=0.74\right)$ and the mean value of $\mathrm{PD}_{2}$ was 6.5. The antagonism was reverted after $60 \mathrm{~min}$ in the absence of SA-MeOH and isojuripidine. SA-MeOH or isojuripidine present a spasmolytic effect in guinea-pig ileum due, in part, to a blockade of the calcium influx through voltageoperated calcium channels $\left(\mathrm{Ca}_{\mathrm{v}}\right)$ channels.

\section{Discussion}

These results show that leaves of S. asterophorum Mart. present secondary metabolites with non-selective spasmolytic action in guinea-pig ileum, isojuripidine being one of them. In the present work, we have investigated the effects of the methanol extract (SA-MeOH) and isojuripidine on isolated guinea-pig ileum. The most important finding of this work is the demonstration, for the first time, that $\mathrm{SA}-\mathrm{MeOH}$ and isojuripidine exert a non-selective spasmolytic action, and that this effect is due in part to the inhibition of $\mathrm{Ca}^{2+}$ influx probably through $\mathrm{Ca}_{\mathrm{v}}$ channels.

The absence of the significant difference between the $\mathrm{IC}_{50}$ values of $\mathrm{SA}-\mathrm{MeOH}$ and isojuripidine on acetylcholine- or histamine-induced contractions in guinea-pig ileum may be suggestive that $\mathrm{SA}-\mathrm{MeOH}$ and isojuripidine are acting by a similar mechanism of action common to these agents.

Two general forms of excitation initiate the contraction of smooth muscles. The initiation of contraction may occur due to innervation and consequent depolarization of the membrane's resting potential, termed electromechanical coupling, whereas activation by ligands of cell surface receptors has been termed pharmacomechanical coupling (Somlyo and Somlyo, 2000). The electrical component of smooth muscle cell excitation is accounted by action potentials, triggering the influx of $\mathrm{Ca}^{2+}$ through voltage-dependent $\mathrm{Ca}^{2+}$ channels. This rise in intracellular $\mathrm{Ca}^{2+}$ may be augmented by $\mathrm{Ca}^{2+}$-induced $\mathrm{Ca}^{2+}$ release from intracellular stores [for a comprehensive review, see Bolton (2006)]. Many agonists that induce guinea-pig ileum contraction cause a biphasic contraction; in the first phase the muscle exhibits a fast and transient contraction followed by a long-lasting second phase, which is characterized by the maintained tonic contraction (Horie et al., 2005). On the other hand, pharmacomechanical coupling involves activation of cell surface receptors to augment the increase in $\mathrm{Ca}^{2+}$, either by the release of $\mathrm{Ca}^{2+}$ from intracellular stores or through cell signaling-mediated mechanisms that increase the $\mathrm{Ca}^{2+}$ sensitivity of the contractile apparatus (Stevens et al., 2000).

To verify whether SA-MeOH and isojuripidine act on $\mathrm{Ca}^{2+}$ influx across the membrane, we evalu- 
A

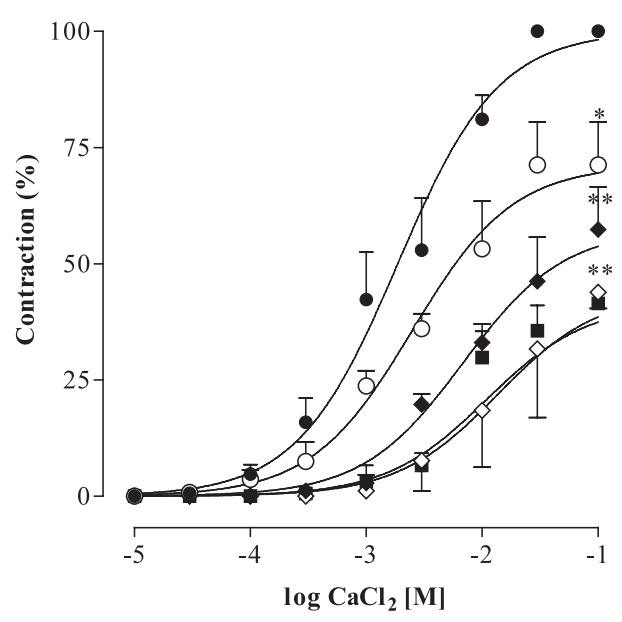

B

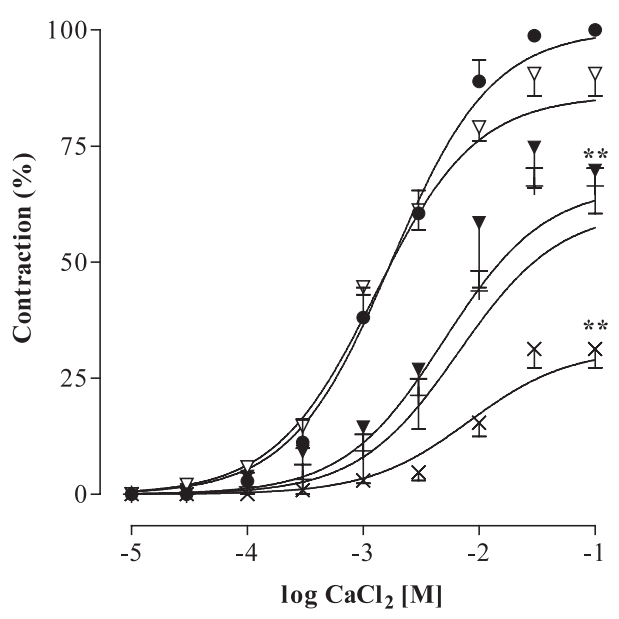

- Control

SA-MeOH:

○ $27 \mu \mathrm{g} / \mathrm{mL}$

$-243 \mu \mathrm{g} / \mathrm{mL}$

$\diamond 500 \mu \mathrm{g} / \mathrm{mL}$

- $750 \mu \mathrm{g} / \mathrm{mL}$
- Control

Isojurupidine:

$\nabla \quad 3 \times 10^{-8} \mathrm{M}$

> $10^{-6} \mathrm{M}$

$+3 \times 10^{-5} \mathrm{M}$

$\times 3 \times 10^{-4} \mathrm{M}$

Fig. 5. Effect of SA-MeOH (A) and isojuripidine (B) on the cumulative concentration-response curves to $\mathrm{CaCl}_{2}$ in depolarizing medium nominally without $\mathrm{Ca}^{2+}$ in guinea-pig isolated ileum $(n=5)$. Symbols and vertical bars represent means \pm S.E.M. Significant differences are indicated by $* p<0.05$ and $* * p<0.001$ (control $\times \mathrm{SA}-\mathrm{MeOH}$ or isojuripidine; one-way ANOVA followed by Bonferroni's test).

ated its effect on the tonic component of the contractile response induced by either acetylcholine or histamine (pharmacomechanical and electromechanical coupling) and $\mathrm{KCl}$ (electromechanical coupling) in the guinea-pig ileum. As shown in Fig. 4, SA-MeOH and isojuripidine relaxed in an equipotent and concentration-dependent manner the ileum pre-contracted with acetylcholine, histamine or $\mathrm{KCl}$. Independently whether the contraction is evoked by either pharmacomechanical or electromechanical coupling, the maintenance of the tonic component involves activation of the $\mathrm{Ca}_{\mathrm{v}}$ channels (Rembold, 1996). Therefore we can postulate that SA-MeOH and isojuripidine may inhibit the $\mathrm{Ca}^{2+}$ influx through these channels to produce non-selective spasmolytic effects.
We confirm the hypothesis that SA-MeOH and isojuripidine inhibit the $\mathrm{Ca}^{2+}$ influx through $\mathrm{Ca}_{\mathrm{v}}$ channels, on cumulative curves to $\mathrm{CaCl}_{2}$ in depolarizing medium nominally without $\mathrm{Ca}^{2+}$ through a non-competitive blockade of $\mathrm{CaCl}_{2}$-induced curves, since SA-MeOH and isojuripidine produced a non-parallel and concentration-dependent downward displacement of the concentration-response to $\mathrm{CaCl}_{2}$, significantly reducing the maximal response.

In conclusion, we have shown that SA-MeOH and isojuripidine produce spasmolytic effects in guinea-pig ileum and that this effect is due in part to the inhibition of the $\mathrm{Ca}^{2+}$ influx through $\mathrm{Ca}_{\mathrm{v}}$ channels. However, we do not discard other possible mechanisms that have not been studied yet. 


\section{Acknowledgements}

The authors thank José Crispim Duarte for providing technical assistance. This work was sup-

Abraham Z., Bhakuni S. D., Garg H. S., Goel A. K., Mehrotra B. N., and Patnaik G. K. (1986), Screening of Indian plants for biological activity. Part XII. Indian J. Exp. Biol. 24, 48-68.

Agra M. F. and Bhattacharyya J. (1999), Ethnomedicinal and phytochemical investigation of the Solanum species in the Northeast of Brazil. In: Solanaceae IV (Nee M., Symon D. E., Lester R. N., and Jessop J. P., eds.). Royal Botanic Gardens, Kew, pp. 341-343.

Almeida E. R., Santos E. R., Lins C. F. B., Mello A. C., Souccar C., and Lapa A. J. (1984), Presença da acetilcolina no fruto de Solanum melongena L. Rev. Inst. Antibiot. 22, 113-120.

Altura B. M. and Altura B. T. (1970), Differential effects of substrate depletion on drug-induced contractions of rabbit aorta. Am. J. Physiol. 219, 1698-1705.

Arunlakshana O. and Schild H. O. (1959), Some quantitative uses of drug antagonists. Br. J. Pharmacol. 14, $48-58$.

Ataíde J. R. (1982), Atividade farmacológica dos extratos da jurubeba roxa, Solanum paludosum Moric., Dissertação (mestrado), Universidade Federal da Paraíba, João Pessoa, Brazil.

Bhakuni O. S., Dhar M. L., Dhar M. M., Dhawan B. N., and Mehrotra B. N. (1969), Screening of Indian plants for biological activity. Part XII. Indian J. Exp. Biol. 7, $250-262$.

Bolton T. B. (2006), Calcium events in smooth muscles and their interstitial cells, physiological roles of sparks. J. Physiol. 570, 5-11.

Boyd L. J. J. (1928), Pharmacology of the homeopathic drugs. Am. Inst. Homeopathy 21, 209.

Daniel E. E., Kwan C. Y., and Janssen L. (2001), Pharmacological techniques for the in vitro study of intestinal smooth muscle. J. Pharmacol. Toxicol. 45, 159.

Friedman M., Rayburn J. R., and Bantle J. A. (1991), Developmental toxicology of potato alkaloids in the frog embryo teratogenesis assay - Xenopus (FETAX). Food Chem. Toxicol. 29, 537-547.

Horie S., Tsuruma K. Y., Someya A., Mirabayashi T., Saito T., Okuma Y., Nomura Y., and Murayama T. (2005), Involvement of cyclooxygenase-dependent pathway in contraction of isolated ileum by urotensin II. Peptides 26, 323-329.

Hunziker A. T. (2001), The Genera of Solanaceae. A. R. G. Gantner Verlag K. G. Liechtenstein, Königstein, p. 500.

Jenkinson D. H., Barnard E. A., Hoyer D., Humphrey P. P. A., Leff P., and Shankley N. P. (1995), International union of pharmacology committee on receptor ported by CAPES and CNPq for grants and fellowships.

nomenclature and drug classification. IX. Recommendations on terms and symbols in quantitative pharmacology. Pharmacol Rev. 42, 255-266.

Nee M. (2001), In: Solanaceae V. Advances in Taxonomy and Utilization (van den Berg R. G., Barendse G. W. M., and van der Weerdsen G. M., Mariani C., eds.). Nijmegen University Press, Nijmegen, pp. 3-22.

Rembold C. M. (1996), Biochemistry of smooth muscle contraction. In: Electromechanical and pharmacomechanical coupling (Bárány M., ed.). Academic Press, San Diego, USA, pp. 227-239.

Ribeiro E. A. N. (2001), Estudo das ações cardiovasculares da fração aquosa do extrato etanólico do caule de Solanum stipulaceum Roem \& Schult. (Solanaceae) em ratos, Dissertação (Mestrado), Universidade Federal da Paraíba, João Pessoa, Brazil.

Ribeiro R., Fiuza De Melo M. M. R., Barros F., Gomes C., and Trolin G. (1986). Acute antihypertensive effect in conscious rats produced by some medical plants used in the state of São Paulo. J. Ethnopharmacol. 15, $261-269$.

Shum O. L. and Chiu K. W. (1991), Hypotensive action of Solanum melongena on normotensive rats. Phytother. Res. 5, 76-81.

Silva J. L. V., Cavalcante F. A., Macêdo L. S., Duarte J. C., Silva T. M. S., and Silva B. A. (2002), Investigação da atividade espasmolítica de Solanum paludosum Moric. (Solanaceae) estudo comparativo entre os extratos etanólico e metanólico. In: Iniciados, $8^{\mathrm{a}}$ série (Souza M. F. W., ed.). Editora Universitária, Universidade Federal da Paraíba, João Pessoa, Brazil, pp. $223-237$.

Silva T. M. S., Batista M. M., Câmara C. A., and Agra, M. F. (2005a), Molluscicidal activity of some Brazilian Solanum spp. (Solanaceae) against Biomphalaria glabrata. Ann. Trop. Med. Parasit. 99, 419-425.

Silva T. M. S., Costa R. A., Oliveira E. J., Barbosa-Filho J. M., Agra M. F., and Câmara C. (2005b), A complete ${ }^{1} \mathrm{H}$ and ${ }^{13} \mathrm{C}$ NMR assignment of isojuripidine from Solanum asterophorum Mart. J. Braz. Chem. Soc. 16, 1467-1471.

Somlyo A. P. and Somlyo A. V. (2000), Signal transduction by G-proteins, Rho-kinase and protein phosphatase to smooth muscle and non-muscle myosin II. J. Physiol. 522, 177-185.

Stevens R. J., Publicover N. G., and Smith T. K. (2000), Propagation and neural regulation of calcium waves in longitudinal and circular muscle layers of guinea pig small intestine. Gastroenterology 118, 892-904

Van Rossum J. M. (1963), Cumulative dose-response curves. Arch. Int. Pharmacodyn. 143, 299-330. 